\title{
Copper isotope evidence of particulate shuttle dynamics in the Late Pennsylvanian North American Midcontinent Sea, with implications for glacio-eustatic magnitude
}

\author{
JINHUA LIU, YU JIAO AND LIAN ZHOU
}

China University of Geosciences (Wuhan)

Presenting Author: liucug2010@163.com

The North American Midcontinent Sea (NAMS) covered a vast area during Late Pennsylvanian glacio-eustatic highstands, providing a laboratory for analysis of the internal watermass dynamics of large cratonic seas (of which few exist in the Recent). A novel proxy, copper isotopes $\left(\delta^{65} \mathrm{Cu}\right)$, was used to gain a better understanding of NAMS watermass dynamics. We analyzed the 63-cm-thick Stark Shale (Dennis Formation, Missourian Stage, Upper Pennsylvanian) in the Iowa Riverton core (IRC) at a centimeter scale in order to reconstruct secular variations in $\delta^{65} \mathrm{Cu}$ and other geochemical proxies. The gray shale facies yielded $\delta^{65} \mathrm{Cu}$ of $+0.02 \pm 0.06 \%$ o $(2 \sigma, n=14)$, similar to detrital $\mathrm{Cu}$ in modern marine sediments $\left(\delta^{65} \mathrm{Cu}=+0.08 \pm\right.$ $0.20 \% ; 2 \sigma, n=42)$. In contrast, the black shale facies, in which the proportion of authigenic $\mathrm{Cu}$ hosted by the organic fraction is $50-100 \%$ of total $\mathrm{Cu}$ content, exhibits heavier $\delta^{65} \mathrm{Cu}_{\text {auth }}$ values, mostly between +0.09 and $+0.43 \%$. In modern marine systems, one of the main processes leading to ${ }^{65} \mathrm{Cu}$-enriched sediment compositions is adsorption of aqueous $\mathrm{Cu}$ onto $\mathrm{Fe}-\mathrm{Mn}$ particulates. The black shale facies of the Stark Shale exhibits four peaks in $\mathrm{Mo} / \mathrm{U}$ ratios that are indicative of an active particulate shuttle because of the tendency of Mo to adsorb more strongly than $\mathrm{U}$ to $\mathrm{Fe}-\mathrm{Mn}$ particulates. The $\mathrm{Sr} / \mathrm{Ba}$ ratio, a paleosalinity proxy, shows correlated variations, with high values (indicative of more fully marine conditions) linked to low $\mathrm{Mo} / \mathrm{U}$ and light $\delta^{65} \mathrm{Cu}$, and low values (indicative of brackish conditions) linked to high $\mathrm{Mo} / \mathrm{U}$ and heavy $\delta^{65} \mathrm{Cu}$. These considerations suggest that the flux of isotopically heavy $\mathrm{Cu}$ to the sediment-water interface via Fe-Mn cycling was enhanced during brackish intervals, with subsequent reductive dissolution of $\mathrm{Fe}-\mathrm{Mn}$ particulates allowing transfer of hydrogenous $\mathrm{Cu}$ to the organic fraction of the sediment. Control of $\delta^{65} \mathrm{Cu}$ by $\mathrm{Fe}-\mathrm{Mn}$ cycling is supported by the results of a sequential extraction experiment showing that organic $\delta^{65} \mathrm{Cu}$ is positively correlated with $\mathrm{Mo} / \mathrm{U}$. These findings provide evidence of large fluctuations in watermass salinity and sea-level elevation within the NAMS at timescales of $\sim 10^{4} \mathrm{yr}$ during core shale deposition, as previously inferred but not conclusively demonstrated until now. 